\title{
SOCIAL INTERACTION OF STUDENTS BASED ON SMARTPHONE ADDICTION LEVEL IN PUBLIC HIGH SCHOOL 21 OF MAKASSAR
}

\author{
Rezki Yusfa Seftiani ${ }^{1}$, Nurhaya Nurdin ${ }^{2}$, Akbar Harisa $^{3}$, Hapsah $^{4}$, Nuurhidayat \\ Jafar $^{5}$ \\ 1,2,3,4,5 Nursing Study Program, Universitas Hasanuddin Makassar \\ e-mail: rezki.yusfa@yahoo.co.id
}

\begin{abstract}
Introduction: Smartphone is currently a tool for communications that is widely used by all people, especially among high school students. Excessive use of smartphone can lead to smartphone addiction. Someone who has a smartphone addiction have anti-social behavior towards his environment. This study aimed to describe of social interaction on the male and female students who have a smartphone addiction in SMA Negeri 21 Makassar. Methode: This study design used is quantitative with descriptive survey. Selection of sample using cluster random sampling, total 95 respondent. Primary data obtained through questionnaires. Result: Based on the results of a study of 95 respondents, shows that respondents who experienced low-level smartphone addiction 19 people $(28.8 \%)$ had a high social interaction, similar with respondents who experienced medium-level of smartphone addiction 43 people $(65.2 \%)$ and high-level 4 people (6.1\%) had a high social interaction. Conclusions: The study concluded that all levels of smartphone addiction has a high social interaction, not all respondents who use smartphones tend to be indifferent to his surroundings. They remain more comfortable communicating directly with the people closest. This research is expected can provide benefits that can be used as information specifically for students of SMAN 21 Makassar, and can improve socialization skills in the environment so that it can improve social interaction began to crushed.
\end{abstract}

Key words : smartphone addiction, social interaction, high school students

\section{PENDAHULUAN}

Smartphone adalah perangkat populer yang mampu memproses informasi lebih lanjut, selain untuk berkomunikasi smartphone memiliki fitur menarik seperti game, akses internet dan media sosial, video call, dan navigasi. Akses ke internet juga semakin mudah karena teknologi mobile dan prevalensi smartphone yang semakin berkembang (Demirici, Akgönül, \& Akpinar, 2015). Menurut International Data Corporation (2013) terdapat lebih dari 1,5 milliar pengguna Smartphone di dunia, dan telah diperkirakan bahwa pada tahun 2016 lebih dari 1 milliar smartphone akan terjual (International data corporation, 2013).

Penggunaan smartphone yang berlebihan dapat menyebabkan ketergantungan atau smartphone addiction, di dalam sebuah penelitian menyebutkan bahwa peningkatan frekuensi dan waktu yang dihabiskan untuk menggunakan smartphone memilki keterkaitan dengan keparahan kecanduan smartphone atau smartphone addiction (Lee, Ahn, Choi, \& Choi, 2014). Hal ini sejalan dengan laporan terbaru dari Bank of America tentang penggunaan smartphone, dilaporkan bahwa 89\% orang Amerika memeriksa smartphone mereka "setidaknya beberapa kali sehari" dan sebanyak 36\% mengakui bahwa mereka secara terus-menerus menggunakan smartphone. $11 \%$ responden mengatakan mereka bisa tanpa smartphone kurang dari satu jam, lebih dari setengah responden sebesar $52 \%$ memeriksa smartphone 
setidaknya 5-10 menit, 31\% memeriksa smartphone setiap 15-30 menit, dan $17 \%$ memeriksa smartphone lebih sering (Braun Reseach Inc, 2015).

Indonesia mendapatkan peringkat sebagai penduduk yang mengalami ketergantungan smartphone tertinggi di dunia, menggunakan smartphone ratarata 3 jam sehari, menurut sebuah studi terbaru oleh MillwardBrown (2014). Studi ini menunjukkan bahwa orang Indonesia menghabiskan waktu dengan smartphone rata-rata 181 menit per hari, lebih dari negara-negara lainnya. Menurut riset yang dilakukan Google Indonesia menjelaskan bahwa 61 persen masyarakat perkotaan Indonesia online dengan menggunakan smartphone-nya dalam total waktu 5,5 jam per hari (Liputan6.com, 2015).

Maraknya penggunan smartphone ini, memunculkan fenomena lain yang dapat dilihat yaitu pengguna smartphone seakan memilki dunianya sendiri di dalam smartphone tersebut. Sering terlihat bahwa seseorang hanya sibuk sendiri dengan smartphonenya, dan tidak memperhatikan lingkungan sekitarnya. Keadaan seperti ini membuat pengguna smartphone menjadi anti-sosial di kehidupan nyata (Saputra, 2014).

Orang-orang yang memiliki percakapan tanpa adanya smartphone memilki tingkat kepedulian atau empati yang lebih tinggi daripada orang-orang yang memiliki percakapan dengan adanya smartphone, mereka cenderung memiliki tingkat empati lebih rendah atau kurang ramah satu sama lain (Misra, Cheng, Genevie, \& Yuan, 2016).

Saat ini smartphone sangat disukai oleh berbagai kalangan khususnya remaja, Pew Research Center menjelaskan bahwa 88\% remaja Amerika berusia 13-17 tahun memiliki berbagai jenis ponsel, mayoritas remaja
73\% memiliki smartphone dan 21\% memilki basic phone (Lenhart, 2015). Banyak remaja di lingkungan pelajar rerata memiliki smartphone khususnya pada pelajar SMA.

Terkait fenomena smartphone addiction ini, maka peneliti tertarik untuk melakukan penelitian tentang gambaran interaksi sosial berdasarkan tingkat smartphone addiction pada siswa-siswi di SMA Negeri 21 Makassar.

\section{METODE}

Penelitian ini menggunakan rancangan penelitian kuantitatif dengan pendekatan survey deskriptif. Populasi pada penelitian ini adalah seluruh siswa dan siswi SMA Negeri 21 Makassar, yaitu sebesar 1651 siswa dan siswi pengguna smartphone dimana sampel pada penelitian ini 95 siswa dan siswi. Teknik pengambilan sampel yang digunakan yaitu probability sampling. Metode yang digunakan yaitu cluster random sampling.

Penelitian ini telah dilaksanakan pada bulan Agustus - November 2016. Pengambilan data dilaksanakan pada tanggal 14-15 November 2016 di SMA Negeri 21 Makassar.

Instrumen penelitian ini berupa kuesioner yang diadaptasi dari menggunakan Korean Smartphone Addiction Scale (K-SAS) dan kuesioner interaksi sosial yang telah dimodifikasi dari Astiti (2013).

\section{HASIL}

Karakteristik responden Kebanyakan responden berusia pada rentang $14-16$ tahun $(71,6 \%)$. Lebih dari setengah responden berjenis kelamin perempuan yakni 59 orang $(62,1 \%)$. Kelas XII merupakan kelas yang memiliki responden terbanyak yaitu 34 orang siswa dan siswi $(35,8 \%)$ (tabel 1). 


\begin{tabular}{lcc}
\hline Karakteristik & Frekuensi & Persentasi (\%) \\
\hline Usia: & 68 & $71,6 \%$ \\
$14-16$ tahun & 27 & $28,4 \%$ \\
17-18 tahun & & \\
\hline Jenis Kelamin: & 36 & $37,9 \%$ \\
Laki-laki & 59 & $62,1 \%$ \\
Perempuan & & \\
\hline Kelas: & 33 & $34,7 \%$ \\
Kelas X & 28 & $29,5 \%$ \\
Kelas XI & 34 & $35,8 \%$ \\
Kelas XII & & \\
\hline
\end{tabular}

Tabel 1. Distribusi frekuensi data demografi yaitu usia, jenis kelamin, dan kelas

\begin{tabular}{|c|c|c|}
\hline Karakteristik Responden & Frekuensi (f) & Persentasi (\%) \\
\hline \multicolumn{3}{|l|}{ Waktu penggunaan smartphone: } \\
\hline Setiap hari & 94 & 98,9 \\
\hline Setiap minggu & 1 & 1,1 \\
\hline \multicolumn{3}{|l|}{ Tujuan penggunaan smartphone: } \\
\hline Media social dan hiburan & 1 & 1,1 \\
\hline Media social\& pencarian informasi & 2 & 2,1 \\
\hline Media social \& sarana komunikasi & 1 & 1,1 \\
\hline Pencerian informasi \& sarana komunikasi & 3 & 3,2 \\
\hline $\begin{array}{l}\text { Media social, hiburan \& sarana pencarian } \\
\text { informasi }\end{array}$ & 14 & 14,7 \\
\hline $\begin{array}{l}\text { Mesia social, hiburan \& sarana } \\
\text { komunikasi }\end{array}$ & 5 & 5,3 \\
\hline $\begin{array}{l}\text { Media social, pencarian informasi, \& } \\
\text { sarana komunikasi }\end{array}$ & 4 & 4,2 \\
\hline Semua pilihan & 65 & 68,4 \\
\hline \multicolumn{3}{|l|}{ Lama penggunaan smartphone: } \\
\hline 1-2 jam/hari & 11 & 11,6 \\
\hline $2-4 \mathrm{jam} / \mathrm{hari}$ & 33 & 34,7 \\
\hline$>4 \mathrm{jam} / \mathrm{hari}$ & 51 & 53,7 \\
\hline \multicolumn{3}{|l|}{$\begin{array}{l}\text { Frekuensi rata-rata penggunaan } \\
\text { smartphone/ jam: }\end{array}$} \\
\hline$<5 \mathrm{kali} / \mathrm{jam}$ & 49 & 51,6 \\
\hline $6-10 \mathrm{kali} / \mathrm{jam}$ & 36 & 37,9 \\
\hline$>10 \mathrm{kali} / \mathrm{jam}$ & 10 & 10,5 \\
\hline \multicolumn{3}{|l|}{$\begin{array}{l}\text { Total biaya pulsa yang dikeluarkan setiap } \\
\text { bulannya: }\end{array}$} \\
\hline Rp. $10.000-R p .50 .000$ & 74 & 77,9 \\
\hline Rp.55.000-Rp.100.000 & 21 & 22,1 \\
\hline \multicolumn{3}{|l|}{$\begin{array}{l}\text { Pulsa pada smartphone digunakan untuk } \\
\text { keperluan: }\end{array}$} \\
\hline Telpon \& SMS & 2 & 2,1 \\
\hline Kuota dan internet & 46 & 48,4 \\
\hline Semua pilihan & 47 & 49,5 \\
\hline \multicolumn{3}{|l|}{$\begin{array}{l}\text { Ada kebijakan sekolah terkait penggunaan } \\
\text { smartphone: }\end{array}$} \\
\hline $\begin{array}{l}\text { Ya (tidak diperbolehkan menggunakan } \\
\text { smartphone saat jam pelajaran) }\end{array}$ & 95 & 100 \\
\hline Tidak & 0 & 0 \\
\hline
\end{tabular}

Tabel 2. Distribusi frekuensi penggunaan smartphone pada responden. ( $n=95$ )

Tabel 2 menunjukkan bahwa hampir semua responden yakni 94 orang $(98,9 \%)$ menggunakan smartphone mereka setiap hari, dan kebanyakan responden yaitu 65 orang $(68,4 \%)$ menggunakan smartphone 
mereka dengan tujuan mengakses media sosial, sebagai media hiburan, dan sebagai sarana komunikasi dan pencari informasi. Dalam hal lama penggunaan smartphone, lebih dari setengah responden yaitu 51 orang $(53,7 \%)$ menggunakan smartphone mereka selama $>4$ jam/hari dan kebanyakan dari mereka menggunakan smartphone dengan frekuensi rata-rata $<5 \mathrm{kali} / \mathrm{jam}$ yakni 49 orang $(51,6 \%)$.
74 orang responden mengakui bahwa total biaya pulsa yang mereka gunakan setiap bulannya berkisar antara Rp. 10.000- Rp.50.000, dan mayoritas dari mereka yakni 47 orang $(49,5 \%)$ menggunakan pulsa untuk telpon, SMS dan juga kuota internet. Semua responden yakni 95 orang siswa dan siswi $(100 \%)$ mengakui bahwa ada kebijakan/ aturan yang diberlakukan terkait penggunaan smartphone.

\begin{tabular}{ccc}
\hline Smartphone Addiction & Frekuensi (f) & Persentasi (\%) \\
\hline Rendah & 24 & 25,3 \\
Sedang & 65 & 68,4 \\
Tinggi & 6 & 6,3 \\
\hline
\end{tabular}

Tabel 3. Gambaran tingkat smartphone addiction pada siswa siswi di SMA Negeri 21 Makassar.

\begin{tabular}{|c|c|c|c|c|c|c|c|c|}
\hline & \multicolumn{6}{|c|}{ Kategori } & \multirow{2}{*}{\multicolumn{2}{|c|}{ Total }} \\
\hline & \multicolumn{2}{|c|}{ Rendah } & \multicolumn{2}{|c|}{ Sedang } & \multicolumn{2}{|c|}{ Tinggi } & & \\
\hline & $\mathbf{f}$ & $\%$ & $\mathbf{f}$ & $\%$ & $\mathbf{f}$ & $\%$ & $\mathbf{f}$ & $\%$ \\
\hline Daily life disturbance & 26 & 27,4 & 52 & 54,7 & 17 & 17,9 & 95 & 100 \\
\hline Virtual world & 25 & 26,3 & 67 & 70,5 & 3 & 3,2 & 95 & 100 \\
\hline $\begin{array}{l}\text { Orientation } \\
\text { withdrawal }\end{array}$ & 62 & 65,3 & 19 & 20 & 14 & 14,7 & 95 & 100 \\
\hline tolerance & 13 & 13,7 & 22 & 23,2 & 60 & 63,2 & 95 & 100 \\
\hline
\end{tabular}

Tabel 4. Gambaran tingkat smartphone addiction berdasarkan karakteristik smartphone addiction pada siswa dan siswi SMA Negeri 21 Makassar $(\mathrm{n}=95)$

\begin{tabular}{|c|c|c|c|c|c|c|c|c|}
\hline \multirow{3}{*}{ Jenis kelamin } & \multicolumn{4}{|c|}{ Smartphone Addiction } & & & \multirow{2}{*}{\multicolumn{2}{|c|}{ Total }} \\
\hline & \multicolumn{2}{|c|}{ Rendah } & \multicolumn{2}{|c|}{ Sedang } & \multicolumn{2}{|c|}{ Tinggi } & & \\
\hline & f & $\%$ & f & $\%$ & $\mathbf{f}$ & $\%$ & $\mathbf{f}$ & $\%$ \\
\hline Laki-laki & 9 & 25 & 26 & 72,2 & 1 & 2,8 & 35 & 100 \\
\hline Perempuan & 15 & 25,4 & 39 & 66,1 & 5 & 8,5 & 60 & 100 \\
\hline
\end{tabular}

Tabel 5. Gambaran tingkat smartphone addiction berdasarkan jenis kelamin pada siswa dan siswi SMA Negeri 21 Makassar.

\begin{tabular}{|c|c|c|c|c|c|c|c|c|}
\hline \multirow{3}{*}{ Usia } & \multicolumn{6}{|c|}{ Smartphone Addiction } & \multirow{2}{*}{\multicolumn{2}{|c|}{ Total }} \\
\hline & \multicolumn{2}{|c|}{ Rendah } & \multicolumn{2}{|c|}{ Sedang } & \multicolumn{2}{|c|}{ Tinggi } & & \\
\hline & $\mathbf{f}$ & $\%$ & $\mathbf{f}$ & $\%$ & $\mathbf{f}$ & $\%$ & $\mathbf{f}$ & $\%$ \\
\hline 14-16 tahun & 17 & 25 & 46 & 67,6 & 5 & 7,4 & 68 & 100 \\
\hline $17-18$ tahun & 7 & 25,9 & 19 & 70,4 & 1 & 3,7 & 27 & 100 \\
\hline
\end{tabular}

Tabel 6. Gambaran tingkat smartphone addiction berdasarkan usia pada siswasiswi SMA Negeri 21 Makassar.

\begin{tabular}{ccc}
\hline Interaksi Sosial & Frekuensi (f) & Persentasi (\%) \\
\hline Rendah & 0 & 0 \\
Sedang & 29 & 30,5 \\
Tinggi & 66 & 69,5 \\
\hline
\end{tabular}

Tabel 7. Gambaran interaksi sosial siswa-siswi SMA Negeri 21 Makassar. (n=95)

Pada tabel 3 dapat dilihat bahwa, responden yang mengalami smartphone addiction tingkat rendah yakni 24 orang siswa dan siswi $(25,3 \%)$, mayoritas responden mengalami smartphone addiction tingkat sedang yakni 65 
orang siswa dan siswi $(68,4 \%)$, dan 6 orang responden $(6,3 \%)$ mengalami smartphone addiction tingkat tinggi.

Berdasarkan tabel 4 dapat dilihat bahwa responden memiliki karakteristik yang memiliki kategori tertinggi yaitu karakteristik tolerance yakni 63,2\%, sedangkan karakteristik smartphone addiction yang memiliki kategori terendah yaitu karakteristik withdrawal symptom yakni 65,3\%. Pada tabel 5 dapat dilihat bahwa jenis kelamin laki-laki dan perempuan kebanyakan mengalami smartphone addiction tingkat sedang, dengan persentasi $72,2 \%$ dan perempuan $66,1 \%$. Pada smartphone addiction tingkat tinggi didominasi oleh jenis kelamin perempuan yakni $8,5 \%$.
Pada tabel 6 ini dapat dilihat bahwa responden yang memiliki tingkat smartphone addiction yang sedang sebagian besar berada pada rentang usia 14-16 tahun yakni 46 orang $(67,6 \%)$, sama halnya dengan responden yang memiliki tingkat smartphone addiction yang tinggi juga berada pada rentang usia 14-16 tahun yaitu 5 orang $(7,4 \%)$.

Pada tabel 7 ini dapat dilihat, bahwa tidak ada responden yang memiliki interaksi sosial yang rendah, kebanyakan responden memiliki tingkat interaksi sosial yang tinggi yaitu 66 orang $(69,5 \%)$, sisanya 29 orang $(30,5 \%)$ memiliki interaksi sosial pada tingkat sedang.

\begin{tabular}{|c|c|c|c|c|c|c|c|c|}
\hline \multirow{3}{*}{$\begin{array}{c}\text { Bentuk Interaksi } \\
\text { Sosial }\end{array}$} & \multicolumn{6}{|c|}{ Kategori } & \multirow{2}{*}{\multicolumn{2}{|c|}{ Total }} \\
\hline & \multicolumn{2}{|c|}{ Rendah } & \multicolumn{2}{|c|}{ Sedang } & \multicolumn{2}{|c|}{ Tinggi } & & \\
\hline & $\mathbf{f}$ & $\%$ & $\mathbf{f}$ & $\%$ & f & $\%$ & f & $\%$ \\
\hline Kerjasama & 0 & 0 & 70 & 73,7 & 25 & 26,3 & 95 & 100 \\
\hline Persesuaian & 0 & 0 & 39 & 41,1 & 56 & 58,9 & 95 & 100 \\
\hline Perpaduan & 0 & 0 & 25 & 26,3 & 70 & 73,7 & 95 & 100 \\
\hline
\end{tabular}

Tabel 8. Gambaran interaksi social berdasarkan bentuk interaksi sosial pada siswa siswi SMA Negeri 21 Makassar.

\begin{tabular}{lcccccccc}
\hline \multirow{3}{*}{ Jenis Kelamin } & \multicolumn{9}{c}{ Kategori } & \multicolumn{2}{c}{ Total } \\
\cline { 2 - 9 } & \multicolumn{2}{c}{ Rendah } & \multicolumn{2}{c}{ Sedang } & \multicolumn{2}{c}{ Tinggi } & \multicolumn{1}{c}{ \% } \\
\cline { 2 - 9 } & $\mathbf{f}$ & $\mathbf{\%}$ & $\mathbf{f}$ & $\mathbf{\%}$ & $\mathbf{f}$ & $\mathbf{\%}$ & $\mathbf{f}$ & $\mathbf{\%}$ \\
\hline Laki-laki & 0 & 0 & 14 & 41.7 & 21 & 58.3 & 35 & 100 \\
Perempuan & 0 & 0 & 15 & 23.7 & 45 & 76.3 & 60 & 100 \\
\hline
\end{tabular}

Tabel 9. gambaran interaksi social berdasarkan jenis kelamin pada siswa-siswi SMA Negeri 21 Makassar.

\begin{tabular}{|c|c|c|c|c|c|c|c|c|}
\hline \multirow{3}{*}{ Usia } & \multicolumn{6}{|c|}{ Interaksi Sosial } & \multirow{2}{*}{\multicolumn{2}{|c|}{ Total }} \\
\hline & \multicolumn{2}{|c|}{ Rendah } & \multicolumn{2}{|c|}{ Sedang } & \multicolumn{2}{|c|}{ Tinggi } & & \\
\hline & $\mathbf{f}$ & $\%$ & $\mathbf{f}$ & $\%$ & $\mathbf{f}$ & $\%$ & $\mathbf{f}$ & $\%$ \\
\hline 14-16 tahun & 0 & 0 & 23 & 33,8 & 45 & 66,2 & 68 & 100 \\
\hline $17-18$ & 0 & 0 & 6 & 22,2 & 21 & 77,8 & 27 & 100 \\
\hline
\end{tabular}

Tabel 10. Gambaran interaksi social berdasarkan usia pada siswa siswi SMA Negei 21 Makassar.

\begin{tabular}{|c|c|c|c|c|c|c|}
\hline \multirow{3}{*}{$\begin{array}{c}\text { Tingkat } \\
\text { Smartphone } \\
\text { Addictio }\end{array}$} & \multicolumn{4}{|c|}{ Interaksi Sosial } & \multirow{2}{*}{\multicolumn{2}{|c|}{ Total }} \\
\hline & \multicolumn{2}{|c|}{ Sedang } & \multicolumn{2}{|c|}{ Tinggi } & & \\
\hline & $\mathbf{f}$ & $\%$ & $\mathbf{f}$ & $\%$ & $\mathbf{f}$ & $\%$ \\
\hline Rendah & 5 & 17,2 & 19 & 28,8 & 24 & 25,3 \\
\hline Sedang & 22 & 75,9 & 43 & 65,2 & 65 & 68,4 \\
\hline Tinggi & 2 & 6,9 & 4 & 6,1 & 6 & 6,3 \\
\hline Total & 29 & 30,5 & 66 & 69,5 & 95 & 100 \\
\hline
\end{tabular}

Tabel 11. Gambaran interaksi social berdasarkan tingkatan smartphone addiction pada siswa siswi SMA Negeri 21 Makassar.

Tabel 8 menunjukkan gambaran interaksi sosial berdasarkan bentuk interaksi sosial pada siswa-siswi di SMA Negeri 21 Makassar. Mayoritas 
responden memiliki bentuk kerjasama pada tingkat sedang yaitu 70 orang $(73,7 \%)$. Kebanyakan responden memiliki bentuk persesuaian dan perpaduan yang tinggi yaitu bentuk persesuaian 56 orang responden $(58,9 \%)$ dan bentuk perpaduan 70 orang responden $(73,7 \%)$.

Tabel 9 menunjukkan gambaran interaksi sosial berdasarkan jenis kelamin pada siswa-siswi di SMA Negeri 21 Makassar. Pada tabel ini dapat dilihat bahwa responden yang memiliki interaksi sosial yang tinggi kebanyakan didominasi oleh responden yang berjenis kelamin perempuan yaitu 45 orang $(76,3 \%)$.

Pada tabel 10 dapat dilihat bahwa responden yang memiliki usia pada 14-16 tahun kebanyakan memiliki interaksi sosial yang tinggi $(66,2 \%)$, sama halnya dengan responden yang memiliki usia 17-18 tahun juga sebagian besar memiliki interaksi sosial yang tinggi $(77,8 \%)$.

Pada tabel 11 ini, responden yang mengalami smartphone addiction tingkat rendah 19 orang $(28,8 \%)$ memiliki interaksi sosial yang tinggi, sama halnya dengan responden yang mengalami smartphone addiction tingkat sedang 43 orang $(65,2 \%)$ dan tinggi 4 orang $(6,1 \%)$ kebanyakan memiliki interaksi sosial yang tinggi. Hasil penelitian menyimpulkan bahwa semua tingkatan smartphone addiction memiliki interaksi sosial yang tinggi.

\section{PEMBAHASAN}

\section{Karakteristik Responden}

Karakteristik responden berdasarkan usia pada tabel 1 menunjukkan bahwa usia 14-16 tahun merupakan usia yang paling banyak yaitu 34 orang $(35,8 \%)$ hal ini wajar dikarenakan usia anak SMA pada umumnya berkisar 15-17 tahun. Ditinjau dari jenis kelamin kebanyakan responden didominasi oleh perempuan dan paling banyak duduk di kelas XII, hal ini dikarenakan banyaknya populasi perempuan dan populasi siswa kelas XII di SMA Negeri 21 Makassar.
Pada tabel 2 hasil penunjukkan bahwa waktu penggunaan smartphone hampir semua responden 38,9\% menggunakan smartphone mereka setiap harinya, dan hanya $1,1 \%$ menggunakan smartphone setiap minggunya. Hal ini menunjukkan bahwa kebanyakan responden setiap harinya tidak lepas dari smartphone mereka dan ini juga sejalan dengan penelitian yang dilakukan oleh Ahn, Wijaya, \& Esmoro (2014) yang juga menunjukkan perbedaan yang signifikan antara penggunaan smartphone setiap hari dengan penggunaan smartphone setiap minggu. Pada penelitian ini penggunaan smartphone menunjukkan standar deviasi yang lebih tinggi.

Dilihat dari tujuan penggunaan smartphone kebanyakan dari responden yaitu 65 orang $(68,4 \%)$ menggunakan smartphone untuk mengakses media sosial, sebagai hiburan, untuk mencari informasi dan sebagai sarana komunikasi, dimana kebanyakan responden memilih semua pilihan yang tertera pada kuesioner. Hal ini juga sangat erat kaitannya dengan lama penggunaan smartphone dimana lebih dari setengah dari jumlah responden yaitu 51 orang $(53,7 \%)$ menggunakan smartphone $>4$ jam/ harinya, 33 orang (34,7\%) menggunakan 2-4 jam/hari, dan 11 orang $(11,6 \%)$ menggunakan 1-2 jam/hari. Peneliti menyimpulkan bahwa semakin banyak tujuan penggunaan smartphone semakin lama pula penggunaan smartphone tersebut.

Frekuensi rata-rata penggunaan smartphone/jam yaitu 49 orang $(51,9 \&)$ mengaku menggunakan smartphone mereka $<5 \mathrm{kali} / \mathrm{jam}, 36$ orang $(37,9 \%)$ menggunakan smartphone 6-10 kali/ jam. Kebanyakan dari responden menggunakan smartphone mereka ratarata $1-12 \mathrm{kali} / \mathrm{jam}$. Menurut peneliti, tingginya frekuensi penggunaan smartphone dikarenakan tingginya keinginan pengguna untuk membuka atau mengecek smartphone mereka, menurut salah satu responden yang diwawancarai peneliti saat penelitian, 
responden mengakui bahwa mereka tertarik membuka atau mengecek smartphone mereka dikarenakan notificasi pesan ataupun social media yang muncul pada smartphone mereka sehingga responden sering membuka atau mengecek smartphone-nya.

Peneliti mengemukakan bahwa penggunaan smartphone ini membuat siswa dan siswi cukup banyak mengeluarkan uang dalam sebulan hanya untuk membeli pulsa di smartphone mereka, dan menurut peneliti dilihat dari pengeluaran biaya pulsa setiap bulannya kebanyakan responden memiliki status ekonomi menengah ke atas. Hal ini dibuktikan dengan hasil observasi peneliti yang melihat bahwa beberapa responden atau siswa siswi SMA Negeri 21 Makassar menggunakan 2 handphone, yakni 1 smartphone yang biasanya digunakan untuk keperluan internet dan media social dan 1 basic phone yang biasanya digunakan hanya untuk telpon \& SMS. Meskipun menurut James\& Drennan dan GSMA (2011) dikutip dalam (Aljomaa et al., 2016), dimana tidak ada perbedaan signifikan yang ditemukan dalam penggunaan smartphone karena status ekonomi.

Semua responden yakni 95 orang siswa dan siswi (100\%) mengakui bahwa ada kebijakan/aturan yang diberlakukan sekolah terkait penggunaan smartphone yaitu tidak diperbolehkannya siswa dan siswi menggunakan smartphone saat proses pembelajaran berlangsung. Menurut peneliti aturan tersebut masih belum sepenuhnya dipatuhi oleh siswa dan siswi SMA Negeri 21 Makassar. Hal ini dibuktikan dengan hasil wawancara yang dilakukan peneliti dengan beberapa siswa yang mengaku bahwa terkadang jika guru tidak melihat, mereka mencuri waktu sedikit untuk memainkan smartphone mereka.

\section{Gambaran tingkat smartphone addiction}

Mayoritas responden mengalami smartphone addiction tingkat sedang,hal ini sesuai karakteristik daily life disturbance yang juga menunjukkan tingkat sedang $(54,7 \%)$. Kwon et.al (2013) menjelaskan bahwa daily life disturbance merupakan suatu keadaan dimana pengguna smartphone mengalami kesulitan konsentrasi pada saat kelas dan menunjukkan gejala pusing, penglihatan kabur dan bahkan gangguan tidur dikarenakan penggunaan smartphone. Peneliti menganalisa, responden tidak sepenuhnya mengalami gejala yang dikemukakan oleh Kwon et.al, tidak semua dari mereka mengalami kesulitan konsentrasi saat berada di kelas. Responden yang mengalami daily life disturbance yang tinggi $(17,9 \%)$ mengalami kesulitan belajar dikelas dan juga mengalami penurunan prestasi dikarenakan smartphone. $\mathrm{Hal}$ ini dikarenakan responden atau siswa dan siswi belum bisa menghilangkan smartphone dalam pikiran mereka. Sama halnya dengan daily life disturbance mayoritas responden mengalami virtual life orientation pada tingkat sedang. Menurut peneliti responden atau siswa dan siswi merasa smartphone bukanlah segalanya, karena mereka bisa menutupi kesepian mereka dengan tetap berinteraksi dengan lingkungan sekitar yaitu teman dan keluarga.

Withdrawal symptom merupakan gejala penarikan dimana seseorang yang menggunakan smartphone akan mengalami perasaan cemas atau khawatir berlebihan jika tidak menggunakan smartphone. Hal ini tidak berlaku pada siswa dan siswi SMA Negeri 21 Makassar, mereka tidak merasakan tertekan, cemas atau khawatir yang berlebih jika tidak bisa menggunakan smartphone sehingga mereka masih bisa belajar tanpa adanya smartphone.

Tolerance menurut Kwon et.al (2013) merupakan suatu usaha seseorang untuk berusaha mengontrol penggunaan smartphone tapi selalu gagal untuk melakukannya. Hal ini juga yang dirasakan oleh kebanyakan responden mereka tidak bisa 
mengontrol penggunaan smartphone sehingga menghabiskan jangka waktu yang lebih panjang hanya untuk menggunakan smartphone. Ini juga berkaitan dengan penggunaan smartphone pada responden yang menunjukkan mayoritas responden menggunakan smartphone $>4$ jam/ hari. Tingginya tingkat tolerance pada responden dikarenakan mereka terbiasa menggunakan smartphone untukmenghindari perasaan tidak nyaman atau kebosanan seperti yang dikemukakan oleh Al-Barashdi, Bouazza, \& Jabur (2015) bahwa tingginya tingkat tolerance dikarenakan mereka cenderung menggunakan smartphone untuk menghindari kondisi/perasaan tidak nyaman dan mereka merasa buruk jika mereka tidak bisa menggunakan ponsel mereka.

Hasil penelitian yang ditunjukkan pada tabel 5 mengenai gambaran tingkat smartphone addiction berdasarkan jenis kelamin, responden yang memiliki tingkat smartphone addiction yang sedang dan tinggi didominasi oleh responden yang berjenis kelamin perempuan. Hal ini sejalan dengan penelitian yang dilakukan oleh Abo-Jedi dan Billieux et. al dikutip dalam Aljomaa et al (2016) yang juga menunjukkan hasil penelitian bahwa perempuan lebih banyak yang mengalami smartphone addiction dibandingkan laki-laki. Perempuan cenderung memiliki gaya hiduo dan pola konsumtif yang tinggi dibadingkan laki-laki dan perempuan juga lebih sering dan intens berkomunikasi menggunakan smartphone hal ini didukung oleh Roberts et.al. (2014) yang mengindikasikan perempuan menghabiskan waktu untuk smartphone lebih banyak dibandingkan laki-laki, dan mereka cenderung menggunakan media sosial, dan applikasi untuk keperluan shopping yang sangat identik dengan wanita.

Dilihat dari usia, responden yang mengalami smartphone addiction pada tingkat yang sedang dan tinggi didominasi oleh usia 14-
18 tahun. Menurut peneliti, hal ini dikarenakan pada usia 14-18 tahun ini merupakan usia remaja dimana respon kaum remaja terhadap halhal yang baru termasuk kecanggihan smartphone cukup tinggi dan mereka juga cenderung memiliki kontrol diri yang rendah sehingga hal inilah yang bisa menyebabkan mereka menjadi adiksi terhadap smartphone mereka. Hal ini didukung dengan penelitian yang dilakukan Haug et al. (2015) yang menemukan kecanduan smartphone lebih umum terjadi pada remaja muda (15-16 tahun) dibandingkan dengan orang dewasa muda (19 tahun dan lebih tua).

\section{Gambaran interaksi social}

Pada penelitian ini responden kebanyakan memiliki interaksi sosial yang tinggi dilihat dari aspek atau bentuk kerjasamanya perlu ditingkatkan lagi karena hasil menunjukkan bahwa interaksi sosial yang tinggi memiliki bentuk kerja sama yang sedang $(73,7 \%)$. Hal ini dibuktikan oleh hasil pengisian kuesioner yang menunjukkan kebanyakan responden lebih suka menyelesaikan masalahnya sendiri atau individual yang tinggi, jarang berdiskusi dengan teman untuk menyelesaikan tugas bersama dan kurang bisa diajak berkerjasama dengan yang lain.

Dilihat dari bentuk persesuaian dan perpaduannya interaksi sosial yang tinggi juga didukung dengan bentuk persesuaian (akomodasi) dan perpaduan (asimilasi) yang tinggi pula tingkatannya. Hal ini menunjukkan bahwa responden paham akan penyesuaian sosial dalam berinteraksi yang dibuktikan oleh rata-rata hasil pengisian kuesioner responden sudah bisa berkomunikasi dengan baik dengan siswa dan siswi yang lain, berusaha menghargai pendapat orang lain, selalu memberikan kesempatan kepada teman untuk berpendapat dan selalu tersenyum jika bertemu dengan teman $(58,9 \%)$.

Sedangkan dilihat pada bentuk perpaduan(asimilasi), 
responden kebanyakan memiliki bentuk perpaduan yang tinggi $(73,7 \%)$. Perpaduan adalah proses sosial ditandai dengan adanya usaha mengurangi perbedaan yang terjadi antara individu atau kelompokkelompok manusia dan juga meliputi usaha-usaha untuk mempertinggi kesatuan tindak, sikap dan prosesproses mental dengan memperhatikan kepentingan dan tujuan bersama (Santosa, 2004). Pada hasil pengisian kuesioner memiliki bentuk perpaduan yang tinggi dibuktikan dengan responden selalu membantu teman mereka ketika mengalami kesusahan, dan sering mengobrol bersama teman di kelas.

Pada hasil yang dijelaskan pada tabel 9 tentang gambaran interaksi sosial berdasarkan jenis kelamin pada siswa-siswi di SMA Negeri 21 Makassar, menunjukkan responden yang memiliki interaksi sosial yang tinggi didominasi oleh responden yang berjenis kelamin perempuan(76,3\%). Menurut Hurlock dikutip dalam Utaminingsih (2006) remaja perempuan cenderung memiliki tingkat kedekatan yang dalam dengan orang-orang sekitarnya dibandingkan dengan remaja laki-laki. Hal ini dikarenakan remaja laki-laki ingin menunjukkan kemandirian yang lebih dan adanya jarak dengan sekitarnya.

Berdasarkan usia, responden yang memiliki interaksi sosial yang tinggi didominasi oleh responden yang berada pada usia 14-18 tahun. Menurut peneliti hal yang mempengaruhi remaja memiliki interaksi sosial yang tinggi yaitu kelompok teman sebaya atau persahabatan sesuai dengan observasi dan hasil wawancara kepada salah satu responden bahwa kebanyakan dari mereka memiliki teman dekat atau sahabat. Mappiare dalam Utaminingsih (2006) menjelaskan dengan adanya persahabatan dalam masa remaja ini, mereka dapat berkerjasama untuk mencapai tujuan bersama, selain itu mereka dapat merasa dibutuhkan, dihargai dan dengan demikian mereka dapat merasa adanya kepuasan dalam interaksi sosialnya.

\section{Gambaran interaksi social berdasarkan tingkat smartphone addiction pada siswa siswi SMA Negeri 21 Makassar}

Hasil penelitian yang disajikan pada tabel 11 menunjukkan bahwa semua tingkatan smartphone addiction memiliki interaksi sosial yang tinggi. Pada penelitian ini memberikan gambaran yang baru mengenai interaksi sosial yang tinggi pada berbagai tingkatan smartphone addiction. Hal ini dikarenakan tidak semua siswa dan siswi yang menggunakan smartphone cenderung acuh tak acuh dengan lingkungan sekitarnya hal ini terbukti dengan hasil pengisian kuesioner yang menunjukkan bahwa siswa dan siswi SMA Negeri 21 Makassar tetap bisa berkerjasama dengan baik, menghargai pendapat temannya, selalu ramah kepada teman dan orang di sekitarnya.

Interaksi sosial secara utuh akan tercipta jika adanya sentuhan secara fisik, baik itu bertegur sapa, berjabat tangan, sehingga nilai-nilai penghargaan, kasih sayang, perhatian akan terwujud (Sunaryo, 2004). Inilah yang tercermin pada siswa dan siswi di SMA Negeri 21 Makassar dimana dari hasil jawaban mereka menunjukkan bahwa mereka selalu tersenyum ketika bertemu dengan teman, dan juga ramah dengan orang lain.

Ameliola \& Nugraha (2013) mengemukakan bahwa faktor sosial adalah faktor yang menggambarkan tentang kebutuhan interaksi sosial. Faktor ini menjelaskan pola interaksi sosial yang mempengaruhi individu menjadi kecanduan smartphone. Cara berkomunikasi menggunakan smartphone membuat kualitas komunikasi tatap muka menurun. Hal ini tidak sejalan dengan hasil penelitian pada siswa dan siswi di SMA Negeri 21 Makassar yang menyatakan bahwa siswa.

\section{KESIMPULAN}

Berdasarkan hasil penelitian 
tentang gambaran interaksi sosial berdasarkan tingkat smartphone addiction pada siswa dan siswi di SMA Negeri 21 Makassar, maka dapat disimpulkan, responden yang kebanyakan memiliki usia 14-16 tahun $(71,6 \%)$ dan didominasi oleh jenis kelamin perempuan $(62,1 \%)$ menggunakan smartphone dengan berbagai tujuan $(68,4 \%)$. Lebih dari setengah responden menggunakan smartphone selama $>4$ jam setiap harinya.Kebanyakan responden mengalami smartphone addiction tingkat sedang $(53,7 \%)$. Lebih dari $2 / 3$ responden memiliki interaksi sosial yang tinggi (69,5\%). Responden yang mengalami smartphone addiction tetap memiliki interaksi sosial yang tinggi, yaitu tingkat rendah 19 orang $(28,8 \%)$, tingkat sedang 43 orang $(65,2 \%)$ dan tinggi 4 orang $(6,1 \%)$. Tidak semua responden yang menggunakan smartphone cenderung acuh tak acuh dengan lingkungan sekitarnya. Mereka tetap lebih nyaman berkomunikasi secara langsung dengan orang terdekat mereka.

\section{DAFTAR PUSTAKA}

Ahn, H., Wijaya, M. E., \& Esmero, B. C. (2014). A systemic smartphone usage pattern analysis: Focusing on smartphone addiction issue. International Journal of Multimedia and Ubiquitous Engineering (Vol. 9). http://doi.org/10.14257/ ijmue.2014.9.6.0 2

Al-Barashdi, H., Bouazza, A., \& Jabur, N. (2015). Smartphone Addiction among University Undergraduates: A Literature Review. Journal of Scientific Research and Reports, 4(3), 210-225. http://doi.org/10.9734/ JSRR/2015/1224 5

Aljomaa, S. S., Mohammad, M. F., Albursan, I. S., Bakhiet, S. F., \& Abduljabbar, A. S. (2016). Smartphone addiction among university students in the light of some variables. Computers in Human Behavior, 61, 155-164. http://doi.org/10.1016/j. chb.2016.03.041

Astiti, D. T. (2013). Meningkatkan kemampuan interaksi social melalui layanan bimbingan kelompok pada siswa program akselerasi SD HJ. Isriati Baiturrahman 01 Semarang. Semarang: Univeristas Negeri Semarang.

Ameliola, S., \& Nugraha, H. D. (2013). Perkembangan media informasi dan tekonologi terhadap anak dalam era globalisasi. The 5th International Conference on Indonesian Studies: "Ethnivity and Globalization," 362-371.

Braun Reseach Inc. (2015). Trends in Consumer Mobility Report. Retrieved from http:// newsroom.bankofamerica.com/files/doc_ library/additional/2015_BAC_Trends_in_ Consumer_Mobility_Report.pdf

Demirici, K., Akgönül, M., \& Akpinar, A. (2015). Relationship of smartphone use severity with sleep quality, depression, and anxiety in university students. FULL LENGTH REPORT Journal of B ehavioral Addictions, 85-92.

Haug, S., Castro, R. P., Kwon, M., Filler, A., Kowatsch, T., \& Schaub, M. P. (2015). Smartphone use and smartphone addiction among young people in Switzerland. Journal of Behavioral Addictions, 4(4), 299-307. http://doi. org/10.1556/2006.4.2015.037

International data corporation. (2013). Worldwide quarterly mobile phone forecast.

Kwon, M., Lee, J. Y., Won, W. Y., Park, J. W., Min, J. A., Hahn, C., ... Kim, D. J. (2013). Development and Validation of a Smartphone Addiction Scale (SAS). PLoSONE, 8(2). http://doi.org/10.1371/ journal.pone.0056 936

Lee, H., Ahn, H., Choi, S., \& Choi, W. (2014). The SAMS: Smartphone addiction management system and verification. Journal of Medical Systems, 38(1). http:/ / doi.org/10.1007/s10916-013-0001-1

Lenhart, A. (2015). Teens, social media and technology overview 2015: Smartphones facilitate shifts in communication landscape for teens. Pew Research Center, (April), 1-47.

MillwardBrown. (2014). AdReaction Marketing in a Multiscreen World.

Misra, S., Cheng, L., Genevie, J., \& Yuan, M. (2016). The iPhone effect the quality of inperson interaction in the precence of mobile device. Environment and Behavior, 48, 275-298

Roberts, J. A., Yaya, L. H. \& Manolis, C. (2014). The invisible addiction: Cell-phone activities and addiction among male and female college students. Journal of Behavioral Addictions, 3(4), 254-265.

Saputra, P. (2014). Fenomena Penggunaan Smartphone Di Kalangan Pelajar (Studi Kasus Di SMP Islam Athirah I Makassar). Universitas Hasanuddin.

Santosa, S. 2004. Dinamika Kelompok. Bandung: Bumi Aksara.

Sunaryo. (2004). Psikologi untuk keperawatan. Jakarta: EGC.

Utaminingsih, I. A. (2006). Pengaruh penggunaan ponsel pada remaja terhadap interaksi sosial remaja. Bogor 